\title{
Attitudes towards and effects of the use of video games in classroom learning with specific reference to literacy attainment
}

\author{
Charles L. Mifsud Centre for Literacy, University of Malta, Malta \\ Rosalind Vella Centre for Literacy, University of Malta, Malta \\ Liberato Camilleri Department of Statistics and Operations Research, \\ University of Malta, Malta
}

\begin{abstract}
The first part of this study shows that there is increased support for using video games in the classroom from different stakeholders, namely students, teachers and parents. The potential role that video games can play in the classroom learning process needs to be more well defined. There is a dire need for research work under experimental conditions which measures tangibly the effectiveness of videogame use in classroom learning. The experimental study described here seeks to address this need and focuses on the very important area of literacy attainment. The Experimental Group of students which used the videogame in the classroom obtained significant gains on a number of English as a Second Language items when compared to the other group of students which followed their regular programme. This study makes a claim for teachers to be supported in their endeavours to harness video games as a teaching and learning tool. However, the role of teachers in this process requires redefinition. It calls also for the concerns of teachers to be addressed if they are to feel they can play a significant role in the adoption of video games in classroom learning.
\end{abstract}

Key words Videogames, Classroom learning, Literacy, English as a Second Language, Experimental study.

\section{Introduction}

Video games can play a significant role in the learning classroom process. In this study students, teachers and parents were surveyed in order to find out what kind and level of support there exists for the use of video games in the classroom situation. Tangible evidence is required for the effectiveness of the use of videogames in classroom learning. In order to obtain such evidence an experimental study was conducted. This study sought to investigate the effects of using a videogame on the learning of a number of 
language skills in a teaching English as a Second Language situation. We sought to investigate whether the group of students which used the videogame in the classroom obtained any significant gains on a number of English as a Second Language items when compared to the other group of students which followed their regular programme. We sought to investigate also how teachers needed to be supported in their endeavours to harness video games as a teaching and learning tool and what teacher concerns about using video games in the classroom are to be addressed.

\section{Review of Literature}

There is increasingly widespread evidence of the positive effects of video games on learning (Coller and Scott, 2009; Echeverria et al., 2011; Green and Bavelier, 2003; Ke and Grabowski, 2007; Klopfer and Squire, 2008; Papastergiou, 2009; Peterson, 2010; Prensky, 2006). Gamers are able to explore different identities and 'inhabit' roles, which would normally be inaccessible to them (Akkerman et al., 2009; Shaffer et al., 2005; Winn, 2002). They are able to alter and change various situations and environments, which in real life would be unalterable; view various phenomena which they may be impossible to witness for real and observe the behaviour of particular environments in different periods of time and changing over time (Rickard and Oblinger, 2004; Squire, 2003, 2008). Video games can be introduced into lessons by using games in class discussions and making links to taught material, introducing some of the fundamentals of video games into teaching in order to make learning more game-like, assigning particular video games as homework, using educational video games and commercial off-the-shelf video games (COTS) for teaching purposes and creating and designing games to suit the learning needs of the class (Prensky, 2006). For learning to be successful, learners need to feel engaged, be aware of the value of their role within the whole process and feel that their investment in the task will bring about progress and goal achievement (Robertson and Howells, 2008). Motivational features which contribute to effective learning are present in video games (Barab et al., 2005; Garris et al., 2002). When carrying out tasks, immediate feedback, whether positive or negative is given, which motivates the player to proceed or to keep trying.

\section{Video games in the classroom}

Students want to use video games in class as they believe that these render the lessons more interesting, while having the opportunity to improve their computer, reaction and problem solving skills, subject knowledge and the ability to work in teams (Sandford et al., 2006; Tao et al., 2009). Students in their early teens and male students (Greenberg et al., 2010) tend to be more predisposed towards the use of video games in lessons. Some students have expressed extreme boredom when using computers at school, which is mainly used for word processing (McFarlane et al., 2002). Students who are more engaged in video games at home are more likely to prefer video 
game use in lessons, find them useful and believe they provide learning opportunities than students who do not have much gaming experience. Some parents agree also that video games can be tools for learning in specific subjects and skills like decision-making, design, strategy and cooperation (McFarlane et al., 2002). On the other hand, Bourgonjon et al. (2011) found that parents' beliefs about video games were somewhat negative, and they were hesitant about the use of video games within education.

Students demonstrate significantly higher intrinsic motivation in video games when compared to the normal school context, namely in challenges, curiosity and particularly in independent mastery (Bellotti et al., 2009; Coller and Scott, 2009; Echeverria et al., 2011; Tuzun et al., 2009). Student engagement, learning, attentiveness, discipline, responsibility, peer collaboration, increased communication by the students with teachers and a meaningful integration of skills can be achieved through the use of video games (Annetta et al., 2009; Rosas et al., 2003), bringing about quicker advancement, enhanced production and increased confidence (Garris et al., 2002). The elements of challenge, reward and success in video games and peer feedback may contribute towards student enthusiasm and motivation to work within the classroom setting to succeed (Robertson and Howells, 2008).

\section{The role of the teachers}

There are teachers who use games in their lessons for different reasons, namely, the motivation of students, inclusive and interactive methods of engaging students and relevance to the topic being taught (Sandford et al., 2006). Some teachers would not consider using video games in their teaching as they deem these to have little or no educational value; they believe there are better types of resources, and there is no time for such activities in the curriculum (Rice, 2007). Other teachers may recognise a number of benefits in using COTS in their lessons, including improved student motor/ cognitive skills, ICT (Information and Communications Technology) skills, higher-order thinking skills, knowledge in a particular area and social skills. There are also teachers who believe that playing video games could lead to antisocial behaviour and stereotypical views of people.

Use of video games for learning enhances student autonomy. In such situations the role of the teacher changes from that of instructor to facilitator or guide (Andrews, 2007; Lim, 2001; Tuzun, 2007). 'Teachable moments' (Watson et al., 2011) are created when the teacher makes links between game play, and teaching and learning concepts. In such situations, students become focused on the learning that could be achieved as they are aware that it may help them in their current game tasks. Hsu and Wang (2010) elaborate that by using guided practice and regular debriefing, learning is scaffolded. Furthermore, teachers take on the role of interpreter, focus on getting the class to think, reflect and make links between what is happening in the game and the main learning aims of the class (Davies, 2007; Hsu and 
Wang, 2010; Mercer et al., 2007). Teachers who have a firm grasp of the subject curriculum are able to utilise the games appropriately to achieve their educational objectives, rather than to just increase familiarity with the game. While in the role of facilitator, teachers need to strike a balance between encouraging open-ended exploration and giving students a certain degree of autonomy, and being able to provide specific instructions at teaching intervals, which will direct the students and keep them on the track of exploration, learning on their own, from their teacher and also from their peers (Bottino et al., 2007; Tuzun, 2007).

Although fun is an important element of video games, teachers need to move beyond this and seek to make explicit to the students the advantages of the use of video games for learning outcomes (Bourgonjon et al., 2010). Lim (2001) calls for a shift towards new teaching and learning practices that include technology.

\section{Video games and literacy}

There exists a 'symbiotic' relationship between ICT and literacy (Andrews, 2007). During game play, the learning of and exposure to words and symbols take place while experiencing the actual reality of these words (Burnett, 2010). Furthermore, video game players research sites and information about the game, read and create game cheats and data about particular levels or tasks in the game and participate in discussion forums (Shaffer et al., 2005). Media-rich early literacy programmes, which include online games, have significant effects on children's literacy development (Penuel et al., 2009). Children who participate in these literacy programmes have significantly better letter-naming and letter-sounding skills and demonstrate significant story and print concepts, and knowledge of letters in their names. Video games, particularly those involving role-play, can have a similar function to books in that they provide students with ideas for their creative writing (Harushimana, 2008). Students may exhibit writing skills in plot development and description of main characters, which have been attained through the video games. Teacher reports claim that students who use video games show improvement in writing skills, higher level sentence and question construction, and basic literacy skills (Owston et al., 2009). In some situations statistically significant gains in spelling and slight gains in reading comprehension were registered after the students played video games (Rosas et al., 2003).

Considerations about the use of video games in classroom learning

Concerns about time limitations and technology difficulties are to be taken into consideration when using video games for learning (Rice, 2007). It is essential that teachers receive support from the school administration (Walsh, 2002) and IT support staff when procuring video games for classroom use, installing them and dealing with technical issues. Difficulties such as incompatible computers and video cards, installation problems and the saving of students' work from session to session need to be considered 
when using video games in the classroom (Kirriemuir and McFarlane, 2003). Difficulties with the timetabling of lessons to be conducted in the computer laboratory and the creation of resources to complement the game are also encountered by teachers. Flexibility is essential for the successful implementation of video games for learning (Tuzun et al., 2009).

The games to be used in the classroom need to be applicable to the content being taught in the curriculum, while also being flexible enough to cater for students at different levels of ability (Barab et al., 2005; MorenoGer et al., 2009). Teachers may need to justify their usage to the school administration and parents (Watson et al., 2011). Teachers reported that although video games provided a vast array of skills, there is oftentimes a discrepancy between game content and curriculum content, making the implementation of video games in schools more difficult (McFarlane et al., 2002). From a learning perspective, the main limitation for video games for learning is that students may not feel they benefit from their use. Some reasons may be that some students do not enjoy using video games or they believe that these should not be implemented in the classroom (Sandford et al., 2006). Furthermore, it may be difficult to measure what students have learnt from a video game.

\section{The present study}

The present study looked at the attitudes of the stakeholders, namely students, teachers and parents, towards the use of video games in classroom learning. An investigation was also conducted into the effects of the use of a video game on classroom literacy attainment. Feedback about the use of the video game in the classroom was obtained from the teachers.

\section{Research methodology}

Attitudes towards the use of video games in education

In order to implement effective use of video games in the classroom, the stakeholders involved, namely, the students, the teachers and the parents, need to demonstrate a positive attitude towards their integration within the curriculum (Papaioannou and Charalambous, 2011; Sanford and Madill, 2007; Selwyn, 1999; Walsh, 2002). The attitudes of pupils, teachers and parents towards the use of video games in education were investigated.

\section{Participants}

The survey was carried out with students, teachers and parents of four Maltese state secondary schools which are single sex secondary schools with a regional catchment area. Students proceed to these schools after having sat for a selective examination. The schools were a girls' secondary school in the south of Malta with a school population of about 838 students, a girls' secondary school in the centre of Malta with a school population of about 720, a boys' secondary school in the centre of Malta with a 
population of 215 and a boys' secondary school in the centre of Malta with a population of about 865 .

The sample consisted of 1163 students with an age range of eleven to sixteen years, 464 were boys and 699 were girls. Furthermore, 149 teachers from the same schools also participated, 47 were male teachers and 102 were female; 783 parents also participated in this research project.

\section{Research instruments}

Survey questionnaires were designed for students, teachers and parents. Students were asked about their opinion on the use of video games in the classroom and their perceptions of what can be learnt from game play. Teachers were asked about their perceptions of the educational potential of video games in school and their use of video games in their lessons. Parents were asked about their perceptions of the potential of video games as an educational tool in school and what video games can teach children.

Three questionnaires were devised: the Student ICT Questionnaire (SQ), the Teacher ICT Questionnaire (TQ) and the Parent ICT Questionnaire (PQ).

\section{The Student ICT Questionnaire (SQ)}

The student survey covered various areas of ICT use, including the use of the computer and the Internet and various other electronic devices. It focused also on students' game play, including both online and COTS (commercial off-the-shelf) computer games, play frequency, duration, location and reasons for play. Students' attitudes towards the use of video games in schools were also investigated.

\section{Design of SQ}

The questionnaire consisted of three sections:

Section A - Demographic Data: in this section, information about pupils' gender, age, name of school, year at school and place of residence was gathered.

Section B - ICT and Video Games: in this section information about the following was collected:

i. Use of various ICT devices;

ii. Reasons for computer and Internet use;

iii. Favourite Internet and computer/video games;

iv. Reasons for game play;

v. Location, frequency and duration of game play;

vi. Persons they play with;

vii. Person they talk to about games;

viii. Perceptions of what can be learnt from game play;

ix. Types and frequency of written work, not related to school, instigated by ICT use. 
Section C - ICT and Video Games in School: in this section the students were asked to express their level of agreement or otherwise with thirteen statements about the use of ICT and game use within the school setting. Furthermore they were asked about how they considered that ICT can be incorporated into classroom teaching and learning.

\section{Teacher ICT Questionnaire (TQ)}

In this part of the survey teachers were asked about their knowledge and use of various ICT tools on their job. They were asked also to rate their perceived level of confidence in using these technologies in the classroom.

\section{Design of TQ}

The questionnaire consisted of three sections:

Section A - Demographic Data: details of gender, age, number of years in teaching, education, levels of classes and subjects taught in the past and being taught presently were obtained.

Section B - General: this included questions on the ICT devices used, reasons for computer and Internet use, number of years of computer use, type of training in ICT and their expertise in specific ICT domains.

Section C - Teaching and School Setting: the frequency and type of ICT use within lessons was investigated, internet use on their job and their perceptions of the educational potential of video games in schools. Teachers then rated how their confidence in using computers during their lessons and how they felt about using mainstream and educational video games to their lessons.

\section{The Parent ICT Questionnaire (PQ)}

The parents were asked to report on their use of ICT tools and on their knowledge of and interest in video games. They were also asked about their children's use of computers and games.

\section{Design of $P Q$}

The PQ consisted of three sections:

Section A - Demographic Data: details of parent's gender, age, place of residence, level of education and occupation were gathered.

Section B - ICT and Video games at home: in this section parents were asked about:

i. use of ICT devices,

ii. reasons for Internet and computer use;

iii. their own and their child's video game and online game play;

iv. frequency and duration of their child's game play;

v. whether they play with their children and frequency; 
vi. whether they discuss games with their children and frequency;

vii. what they thought video games could teach their children.

Section C - ICT and Games in School: parents rated their perceptions of the potential of video games as an educational tool used in a school setting.

\section{Data collection}

The study with the SQ involved all the Form 1, Form 2 and Form 4 students in schools of the study. This involved 1441 students in all with an age range of eleven to sixteen years; 1163 students ( 80.1 per cent), 464 boys and 699 girls, who were present in their respective class on the day of the study, completed the questionnaire. The pupils were asked to complete the survey questionnaire during school hours, under the supervision of their class teacher.

The TQ was distributed to all the teachers who taught the students who were surveyed. From the 240 questionnaires distributed, 149 (62.1 per cent) were completed and returned. This involved 41 male teachers, 96 female teachers and 12 teachers who did not state their gender.

The PQ was distributed to the parents of all Form 1, Form 2 and Form 4 students in the schools of the study. The PQs, with a covering letter, were sent to the parents through their children. They were asked to return the completed questionnaires to the class teacher within one week; 783 questionnaires (54.3 per cent) were returned from the total amount of 1441 that were distributed.

\section{Effects of the use of a video game on literacy attainment}

\section{The video game}

In order to be able to assess the impact of the use of video games on the learning of English as a Second Language in Maltese secondary schools, a number of video games were considered. A major consideration was the opportunity to be able to introduce the use of the game during regular English language lessons in a number of Maltese secondary schools. The contents of the game had to match the relevant English language syllabus items which were being covered in a particular form. The game had also to be acceptable to the English class teachers who were to implement it in their classrooms. Following a number of trials and widespread consultation with a number of English as a Second Language and Information Technology teachers, The ClueFinders Reading Adventures: The Mystery of the Missing Amulet game (The Learning Company) was chosen as it was deemed to be appropriate for the purpose of this study. This type of game is described as a commercial off-the-shelf game and as edutainment software (http://en.wikipedia.org/ wiki/The_ClueFinders_Reading_Adventures). The selected game introduced and provided practice in a number of language items which form part of the secondary school syllabus (Directorate for Quality and Standards in 
Education, 2011). The teachers considered this game to be at an adequate level of difficulty for their students and confirmed that the language items covered in the tasks were relevant to the English curriculum of the classes they were teaching.

The selected video game features five characters, referred to as the ClueFinders, who are on a quest to find missing amulet halves. They must complete challenges and tasks in order to obtain clues, gems and rocks which will help them on their way. This requires careful reading and problem-solving on the part of the players.

\section{Participants in the video game study}

Eighteen classes with an age range of 11-13 years from the four secondary schools already referred to participated in this study. The Experimental Group (EG) was made up of 9 classes consisting of 85 boys ( 4 classes) and 122 girls (5 classes) and had the video game incorporated into their English programme of lessons. The Control Group (CG) was made up of 9 classes consisting of 82 boys (4 classes) and 119 girls (5 classes). They followed regular English as a Second Language classes. Teachers who taught the CG were aware that their classes were involved in the research project, but they were not informed of the specific skills that were being taught through the video game.

\section{Research instruments for the video game study}

An assessment procedure was designed in order to be able to investigate the gains in learning. This assessment included exercises which reflected the English grammar tasks, skills and vocabulary that are outlined in the syllabus. A model test item response was provided at the beginning of each task in order to assist the students' comprehension. The grammatical items and skills assessed in each task were as follows:
A. Vocabulary: categorisation and reasoning,
B. Homonyms and vocabulary,
C. Antonyms,
D. Synonyms,
E. Vocabulary: spelling, prefixes and suffixes,
F. Vocabulary: critical thinking, analogies, attributes, antonyms and synonyms,
G. Grammar: parts of speech and sentence structure (specifically noun, adjective, verb, adverb and preposition),
H. Grammar: parts of speech and sentence structure (specifically verb, subject and direct object),
I. Reading for meaning, vocabulary, main idea, detail and inference.

Furthermore, a feedback questionnaire was designed in order to obtain feedback from the seven teachers in the EG about their experience of 
teaching through the video game, including their role in the class, reaching teaching goals and class management.

\section{Conduct of the experiment}

The data collection for this part of the study took place over a period of six weeks. An initial assessment exercise was conducted in the first week of the study in all the classes (from both the EG and the CG) during a regular English as a Second Language lesson by their regular English teacher in collaboration with a member of the research team. The students were instructed to complete the assessment on an individual basis.

In the second week, the students in the EG became familiar with the video game. They went on to play the game throughout their programme of English lessons for a period of four weeks, with each daily session lasting forty minutes. The students were placed randomly in pairs by the class teachers and each pair played the game collaboratively. Each lesson was structured in a way that students were expected to play and complete specific game sequences. At the beginning of each session, the students were shown on a large screen how to play each game sequence. The teacher answered student questions and then allowed the students to proceed on their own for the rest of the session. The teacher prompted, helped and guided student pairs on a regular basis throughout the lesson. Throughout this period, the CG continued with their English lessons as usual.

Following the test period of four weeks, all the students (from both the EG and the CG) were set the same assessment again during a regular English lesson in the sixth week of the study. Furthermore, the teachers of the EG also completed the feedback questionnaire.

\section{Results}

Attitudes towards video games in education

Most of the students (79.1 per cent) feel that video games can provide them with an opportunity for learning. A significantly higher number of boys and students from the lower forms $(P<0.0005)$ think that video games can provide opportunities for learning. Students believe they can learn a variety of skills from video games. Table 1 presents these skills in rank order according to the number of students who believe they can acquire these skills from video games. A quarter of the students feel that they learn violence and aggression from the games.

The majority of the teachers (77.5 per cent) believe that students can learn through video games, yet only 9.4 per cent of teachers actually use video games in the class. Overall teachers believe that students can learn hand-eye coordination (67.8 per cent) and general knowledge (66.4 per cent) through video game play. Nearly half the sample believes that students can learn aggression and violence through game play (48.3 per cent). Teachers stated that they would use educational video games and 
Table I What students think they learn from video games

\begin{tabular}{lcc}
\hline Skills & Frequency $(n=997)$ & Percentage (\%) \\
\hline How to plan & 567 & 56.9 \\
How to work in a team & 565 & 56.7 \\
Problem-solving & 489 & 49.0 \\
Decision-making & 467 & 46.8 \\
General Knowledge & 377 & 37.8 \\
Logical thinking & 354 & 35.5 \\
Strategy negotiation & 333 & 33.4 \\
Reading & 322 & 32.3 \\
Computer literacy & 320 & 32.1 \\
Social & 274 & 27.5 \\
Hand-eye co-ordination & 265 & 26.6 \\
Spelling & 260 & 26.1 \\
Violence and aggression & 254 & 25.5 \\
\hline
\end{tabular}

mainstream video games if they were relevant to the syllabus (73.9 and 61.4 per cent, respectively).

Most parents believe that educational video games are good tools for classroom learning (82.7 per cent) while only 34.9 per cent of parents think mainstream video games are good tools, with 38.7 per cent of parents being unsure of the potential of videogames and the remaining 26.3 per cent disagreeing. Overall, 68.7 per cent agree that school subjects can be taught through video games. About half the parents believe that children can learn how to work in a team (51.7 per cent) and reading skills (48.1 per cent) through video game play, and notably, only 9.3 per cent of parents believe that violence and aggression can be learnt from video games.

\section{Effects of the use of a video game on literacy attainment}

\section{Assessment results}

Results of the assessment of both the experimental and control groups

Statistical analyses were conducted to investigate the gains in performance, for both the EG and CG, when comparing the mean scores obtained in the pre- and post-tests. Further analyses were conducted to investigate the performance of students from the two groups on the specific tasks.

Differences in mean scores for the experimental and comparison groups

In order to check whether mean scores differed significantly between the EG and CG, a two-independent-samples $t$-test was administered for both the pre- and post-tests. The null hypothesis specifies that the mean scores obtained by the game and comparison groups are comparable and is accepted if the $P$ value exceeds the 0.05 level of significance. The alternative hypothesis specifies that the mean scores differ significantly and is accepted if the $P$ value is less than the 0.05 criterion. The results are presented in Table 2. 
Table 2 Mean scores for the two groups in pre and post tests

\begin{tabular}{llccc}
\hline & Group & Mean score & Std. deviation & P value \\
\hline Pre-test & Experimental & 41.03 & 7.73 & 0.838 \\
& Control & 40.83 & 10.16 & \\
Post-test & Experimental & 48.00 & 7.27 & $0.000 * * *$ \\
& Control & 39.96 & 9.44 & \\
\hline
\end{tabular}

$* * * P<0.001$.

No significant differences in mean scores were obtained for the pre-test. This implies that both groups started off with a similar level of ability. However a significant difference in mean scores was obtained for the post-test, with a higher mean score for the EG. This implies that the level of ability of the game group improved significantly as a result of the intervention. Further analyses were conducted in the next section in order to investigate further these differences between both groups.

Difference between mean scores obtained in the pre- and post-tests by the two groups

In order to check whether differences in mean scores differ significantly between the pre-and post-tests, a paired-sample $t$-test was carried out for both the EG and CG. The null hypothesis, specifying comparable mean scores in pre- and post-tests is accepted if the $P$ value exceeds the 0.05 level of significance. The alternative hypothesis specifying significantly different mean scores is accepted if the p-value is less than the 0.05 criterion. The results are presented in Table 3 .

The mean scores of students in the EG increased significantly in the posttest; however, the mean scores of students in the CG varied marginally in the post-test, and differences were not significant at the 0.05 criterion. These results are illustrated in Figure 1 below.

The two-independent-samples $t$-test was again employed to test whether the gains in performance differed considerably between male and female participants in the experimental group. No significant differences were found. Following the analyses of the combined performance in the pre- and post-tests for both groups, further analyses were carried out to check

Table 3 Mean scores in the pre- and post-tests for the two groups

\begin{tabular}{lcccc}
\hline Group & Test & Mean score & Std. deviation & P value \\
\hline Experimental & Pre-test & 41.03 & 7.73 & $0.000 * * *$ \\
& Post-test & 48.00 & 7.27 & \\
Control & Pre-test & 40.83 & 10.16 & 0.175 \\
& Post-test & 39.96 & 9.44 & \\
\hline
\end{tabular}

***P $<0.001$. 


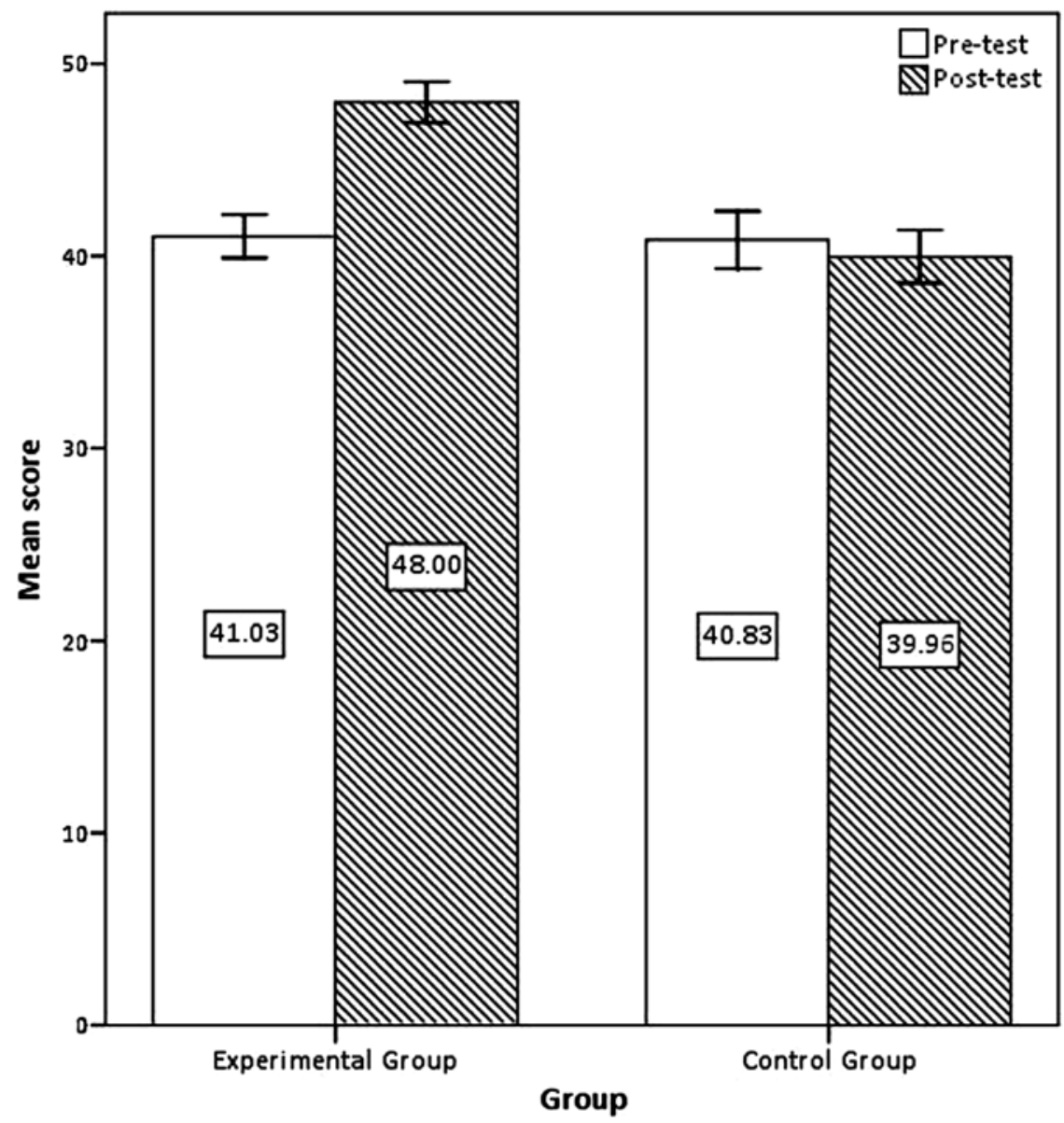

Figure I Mean scores and 95 per cent confidence intervals for the two groups in the pre- and post-tests.

whether performance on specific tasks improved significantly in the posttest for the two groups separately.

The results on each task for the CG

Table 4 presents the mean scores obtained by the CG $(\mathrm{N}=182)$ for each task in both the pre-test and the post-test. The paired-sample $t$-test was again used to test for significant differences between the mean scores using a 0.05 level of significance.

Significant differences were obtained for the test items dealing with vocabulary: categorization and reasoning (A), vocabulary: spelling, prefixes and suffixes (E), and grammar: parts of speech and sentence structure $(G)$. Whereas in the case of the first two items a significant increase in scores was 
Table 4 Mean scores of pre-test and post-test for the CG

\begin{tabular}{cccccc}
\hline Task & $\begin{array}{c}\text { Mean score } \\
\text { Pre-test }\end{array}$ & $\begin{array}{c}\text { Mean score } \\
\text { Post-test }\end{array}$ & $\begin{array}{c}\text { Difference in } \\
\text { mean scores }\end{array}$ & $t$ Value & P value \\
\hline A & 9.21 & 9.52 & 0.31 & 2.510 & $0.013^{*}$ \\
B & 6.75 & 6.59 & 0.16 & 1.030 & 0.304 \\
C & 3.31 & 3.17 & 0.13 & 1.257 & 0.211 \\
D & 2.79 & 2.79 & 0.01 & 0.560 & 0.955 \\
E & 3.16 & 3.43 & 0.26 & 2.732 & $0.007^{* *}$ \\
F & 4.42 & 4.49 & -0.13 & -1.038 & 0.301 \\
G & 5.95 & 5.43 & -0.51 & -2.889 & $0.004^{* *}$ \\
H & 2.06 & 2.14 & 0.08 & 0.795 & 0.428 \\
I & 3.16 & 3.26 & 0.10 & 1.288 & 0.200 \\
\hline
\end{tabular}

$* P<0.05, * P<0.01$.

Tasks: A. Vocabulary: categorisation and reasoning; B. Homonyms and vocabulary, C. Antonyms; D. Synonyms; E. Vocabulary: spelling, prefixes and suffixes;

F. Vocabulary: critical thinking, analogies, attributes, antonyms and synonyms;

G. Grammar: parts of speech and sentence structure (specifically noun, adjective, verb, adverb and preposition); H. Grammar: parts of speech and sentence structure (specifically verb, subject and direct object).

registered in the post-test, in the case of parts of speech, a significant decrease in scores was registered.

\section{The results on each task for the EG}

The same procedure used for the CG was adopted for the EG. Table 5 presents the mean scores obtained by the EG $(\mathrm{N}=184)$ in both the pre-test and the post-test.

Table 5 Mean scores of pre-test and post-test for the EG

\begin{tabular}{ccccrc}
\hline Task & $\begin{array}{c}\text { Mean score } \\
\text { Pre-test }\end{array}$ & $\begin{array}{c}\text { Mean score } \\
\text { Post-test }\end{array}$ & $\begin{array}{c}\text { Difference in } \\
\text { mean scores }\end{array}$ & $t$ Value & P value \\
\hline $\mathrm{A}$ & 9.72 & 10.47 & 0.75 & 6.389 & $\mathbf{0 . 0 0 0 * * *}$ \\
$\mathrm{B}$ & 7.02 & 7.84 & 0.81 & 5.228 & $\mathbf{0 . 0 0 0 * * *}$ \\
$\mathrm{C}$ & 3.36 & 3.61 & 0.25 & 2.377 & $\mathbf{0 . 0 1 8 *}$ \\
$\mathrm{D}$ & 2.74 & 2.93 & 0.19 & 2.271 & $\mathbf{0 . 0 2 4}$ \\
$\mathrm{E}$ & 2.59 & 4.34 & 1.75 & 14.093 & $\mathbf{0 . 0 0 0 * * *}$ \\
$\mathrm{F}$ & 4.67 & 5.22 & 0.55 & 4.329 & $\mathbf{0 . 0 0 0 * * *}$ \\
$\mathrm{G}$ & 6.18 & 7.16 & 0.98 & 5.866 & $\mathbf{0 . 0 0 0 * * *}$ \\
$\mathrm{H}$ & 1.79 & 3.10 & 1.31 & 10.911 & $\mathbf{0 . 0 0 0 * * *}$ \\
$\mathrm{I}$ & 3.04 & 3.63 & 0.58 & 6.216 & $\mathbf{0 . 0 0 0} * *$ \\
\hline
\end{tabular}

$* P<0.05, * * P<0.001$.

Tasks: A. Vocabulary: categorisation and reasoning; B. Homonyms and vocabulary, C. Antonyms; D. Synonyms; E. Vocabulary: spelling, prefixes and suffixes;

F. Vocabulary: critical thinking, analogies, attributes, antonyms and synonyms; G. Grammar: parts of speech and sentence structure (specifically noun, adjective, verb, adverb and preposition); H. Grammar: parts of speech and sentence structure (specifically verb, subject and direct object). 
For the EG, there was a significant increase in mean post-test scores for all the test items.

\section{Difference in performance between the EG and CG on each task}

In order to determine significant differences in performance on each task between the CG and EG, a two-independent-samples $t$-test was carried out. Table 6 presents the results of this analysis.

Significant differences were obtained for all the tasks except for antonyms (C) and synonyms (D).

\section{Teacher feedback}

The seven teachers who implemented the video game in their English as a Second Language provided feedback on the use of the game in the classroom. Six teachers stated that the students were very motivated and enthusiastic to play and learn - 'Something different, therefore more motivating' (teacher aged 30-39, teaching for eight years). Three teachers stated that students were learning informally while having fun. Although the change in routine was an issue, two teachers pointed out that the variety provided by the game was positive. Further advantages according to the teachers were that students were working as a team, using the English language more often than usual, improving their thinking skills as they were applying their learning to various situations, reading and listening to a lot of English throughout the game and learning new words either through meaning in context or by looking them up in the dictionary. One teacher stated that the visuals of the game had a big impact on the students. It was also motivating:

Table 6 Difference between the mean scores of the two groups on each task

\begin{tabular}{lccccc}
\hline Task & $\begin{array}{c}\text { Mean } \\
\text { score CG }\end{array}$ & $\begin{array}{c}\text { Mean } \\
\text { score EG }\end{array}$ & $\begin{array}{c}\text { Difference in } \\
\text { mean score }\end{array}$ & $t$ Value & P value \\
\hline $\mathrm{A}$ & 0.31 & 0.75 & 0.54 & 2.550 & $\mathbf{0 . 0 1 1 ^ { * }}$ \\
$\mathrm{B}$ & 0.16 & 0.81 & 0.49 & 2.959 & $\mathbf{0 . 0 0 3} * *$ \\
$\mathrm{C}$ & 0.13 & 0.25 & 0.19 & 0.781 & 0.435 \\
$\mathrm{D}$ & 0.01 & 0.19 & 0.10 & 1.416 & 0.158 \\
$\mathrm{E}$ & 0.26 & 1.75 & 1.02 & 9.457 & $\mathbf{0 . 0 0 0 * * *}$ \\
$\mathrm{F}$ & -0.13 & 0.55 & 0.22 & 3.814 & $\mathbf{0 . 0 0 0 * * *}$ \\
$\mathrm{G}$ & -0.51 & 0.98 & 0.26 & 6.124 & $\mathbf{0 . 0 0 0}$ \\
$\mathrm{H}$ & 0.08 & 1.31 & 0.72 & 7.931 & $\mathbf{0 . 0 0 0 * * *}$ \\
$\mathrm{I}$ & 0.10 & 0.58 & 0.35 & 3.943 & $\mathbf{0 . 0 0 0}$ \\
\hline
\end{tabular}

*P<0.05, **P<0.01, **P $<0.001$.

Tasks: A. Vocabulary: categorisation and reasoning; B. Homonyms and vocabulary, C. Antonyms; D. Synonyms; E. Vocabulary: spelling, prefixes and suffixes; F. Vocabulary: critical thinking, analogies, attributes, antonyms and synonyms; G. Grammar: parts of speech and sentence structure (specifically noun, adjective, verb, adverb and preposition); H. Grammar: parts of speech and sentence structure (specifically verb, subject and direct object). 
'On the whole, the game proved to be a positive break from the classroom routine; a challenge for the weaker students, and interesting. Only a few students were not interested in it, or did not appreciate its benefits' (teacher aged 30-39, teaching for 18 years). One teacher considered that the main benefit of the game was that: 'It introduced a large element of fun which would have otherwise been missing' (teacher aged over 50, teaching for 27 years).

Four teachers found the game to be relevant to the English syllabus as it covered many grammatical points which pertained to the syllabus and gave students an opportunity to practise their English. In this way teachers could become aware of their students' strengths and weaknesses. 'It exposes student to a useful range of vocabulary which they can use in their writing tasks. Also, playing the game allows them to practice the four language skills' (teacher, aged under 30, teaching for seven years). Another female teacher found the reading for meaning tasks to be highly effective.

The teachers also provided feedback about the difficulties they faced when implementing the video game in their lessons. Four teachers remarked that time availability was a limitation to using video games in their teaching. This was due to the time required to install the games and to set up the computer laboratory. Further concerns were that some students may not have enough English language proficiency to be able to understand the game instructions and that some students progress quicker than others when playing. Also some students may not enjoy playing video games or may get used to playing the game and become bored. Some teachers expressed concern about the fact that some students got stuck at a particular stage of the game and were unable to move on to the next task. They felt that a guidebook to accompany the game play would have helped them to organise better their work in the classroom.

All the teachers said they were keen on using video games again to teach English as they found the video game to be effective. It promoted informal and discovery learning, enhanced the students' enjoyment and engagement and the game tasks were effective. 'The game is very engaging and I believe it can be very useful when combined with classroom instruction' (teacher aged under 30, teaching for seven years). They recognised the need for increased awareness and relevant training and support: 'Teachers need to be made more aware of the usefulness of games in language learning and they also need training and support to be able to implement these in the classroom' (teacher aged under 30, teaching for seven years).

\section{Discussion and conclusion}

The majority of the students, teachers and parents studied here showed themselves to be well-disposed towards the use of video games in classroom learning. Teachers' feedback on the use of the video game in the classroom was generally positive. The teachers involved in the experimental study felt that the use of the video game could be integrated into their regular 
teaching and outlined the benefits of doing so. This generally positive disposition was borne out by the positive and significant gains in results obtained on a number of literacy skills.

The two groups of students who took part in the study, the EG and the CG, started out with similar levels of ability in English as a Second Language. Mean performance scores varied marginally between the groups at the start of the experiment. However a significant gain in performance was attained by the experimental group, but not by the control group, when both groups were tested again at the end of the experiment period. This shows clearly that the pupils who had played the video game as part of their programme of English lessons, throughout the period of the experiment, made significant gains in learning when compared to the control group which had regular English lessons throughout. No significant gender differences resulted from the analysis. Both boys and girls from the experimental group registered similar significant gains in learning at the end of the study.

Further analyses revealed that the control group obtained a significant increase in mean scores on two test items only, whereas the experimental group obtained a significant increase in scores on all the test items that were assessed. In fact on one of the test items, the control group obtained a significant decrease in the mean score. The differences in gains in scores between the two groups were examined further. This showed that the experimental group scored significantly higher on seven assessment tasks out of nine. On the other two tasks there were no significant differences.

From this study, compelling evidence has emerged of the positive and significant effects of using a video game during a programme in English as a Second Language for secondary school students. Students are gradually migrating away from traditional reading and writing as they are increasingly exposed to digital literacies, which require different cognitive and learning skills (Mackereth and Anderson, 2000). This requires a shift in teaching practice in order to engage, motivate and facilitate students to learn. Marsh (2004) demonstrates that literacy skills are even acquired by toddlers (two and a half to four years) through their engagement in technoliteracy practices, and emphasizes the need for the incorporation of such practices into education.

There is widespread support from students, teachers and parents for the use of video games in classrooms. Teachers from this study were generally positive about the effects of using video games in classroom learning, in this case for the teaching of English as a Second Language. There is clear evidence of the gains in learning to support the positive attitudes of students, teachers and parents on the beneficial impact of the use of video games in classrooms. For this to be sustained in a structured way, the necessary curricular and technical support needs to be in place for the integration of videogames in regular classroom teaching and teacher concerns must be addressed in an effective manner. Shields and Behrman (2000) recommend a three-pronged approach for offering support to teachers: 1) further 
teacher training and development 2) organisational and structural support; and 3) school support. Education policy too needs to consider seriously how technology can be incorporated selectively into educational reform as part of an overall programme for improvement (Roschelle et al., 2001).

The study conducted in this article indicates that the use of video games in language learning opens a range of research possibilities. The research presented here provides evidence that participation in gaming may facilitate aspects of literacy attainment. There is a need for more large-scale, longitudinal studies that explore the influence of specific game factors and their application on literacy gains. Future research in this area offers the prospect of enhanced understanding of the complex processes involved in language learning and how these may be facilitated in the dynamic learning environments made possible by video games (Peterson, 2010).

\section{Acknowledgements}

We would like to thank the schools for their co-operation, and all the students, teachers and parents who took part in the study.

\section{References}

Akkerman, S., Admirall, W. and Huizenga, J. (2009), 'Storification in History Education: A Mobile Game in and About Medieval Amsterdam', Computers and Education, 52 (2), 449-59.

Andrews, R. (2007), 'Research on Teaching Secondary English with ICT', in Adams, A. and Brindley, S., Teaching Secondary English with ICT, Berkshire: Open University Press, pp. 126-36.

Annetta, L. A., Minogue, J., Holmes, S. Y. and Cheng, M. (2009), 'Investigating the Impact of Video Games on High School students' Engagement and Learning About Genetics', Computers and Education, 53 (1), 74-85.

Barab, S., Thomas, M., Dodge, T., Carteaux, R. and Tuzun, H. (2005), 'Making

Learning fun: Quest Atlantis, a Game Without Guns', Educational Technology Research and Development, 53 (1), 86-107.

Bellotti, F., Berta, R., De Gloria, A. and Primavera, L. (2009), 'Enhancing the Educational Value of Video Games', ACM Computers in Entertainment, 7 (2), Article 23.

Bottino, R. M., Ferlino, L., Ott, M. and Tavella, M. (2007), 'Developing Strategic and Reasoning Abilities with Computer Games at Primary School Level', Computers and Education, 49 (4), 1272-86.

Bourgonjon, J., Valcke, M., Soetaert, R. and Schellens, T. (2010), 'Students' Perceptions About the use of Video Games in the Classroom', Computers and Education, 54 (4), 1145-56.

Bourgonjon, J., Valcke, M., Soetaert, R., de Wever, B. and Schellens, T. (2011), 'Parental Acceptance of Digital Game-Based Learning', Computers and Education, 57 (1), 1434-44.

Burnett, C. (2010), 'Technology and Literacy in Early Childhood Educational Settings: A Review of Research', Journal of Early Childhood Literacy, 10 (3), 247-70.

Coller, B. D. and Scott, M. J. (2009), 'Effectiveness of Using a Video Game to Teach a Course in Mechanical Engineering', Computers and Education, 53 (3), 900-12. 
Davies, C. (2007), 'What can Technology Do for/to English?', in Adams, A. and Brindley, S., Teaching Secondary English with ICT, Berkshire: Open University Press, pp. 50-66.

Directorate for Quality and Standards in Education (2011), The Sky is the Limit: English Curriculum Units Form 1, Malta: Curriculum Management and eLearning Department.

Echeverria, A., Garcia-Campo, C., Nussbaum, M., Gil, F., Villalta, M., Amestica, M. and Echeverria, S. (2011), 'A Framework for the Design and Integration of Collaborative Classroom Games', Computers and Education, 57 (1), 1127-36.

Garris, R., Ahlers, R. and Driskell, J. E. (2002), 'Games, Motivation, and Learning: A Research and Practice Model', Simulation and Gaming: An Interdisciplinary Journal, 33 (4), 441-67.

Green, C. S. and Bavelier, D. (2003), 'Action Video Game Modifies Visual Selective Attention', Nature, 423 (6939), 534-7.

Greenberg, B. S., Sherry, J., Lachlan, K., Lucas, K. and Holmstrom, A. (2010), 'Orientations of Video Games Among Gender and age Groups', Simulation and Gaming, 41 (2), 238-59.

Harushimana, I. (2008), 'Literacy Through Gaming: The Influence of Videogames on the Writings of High School Freshman Males', Journal of Literacy and Technology, 9 (2), 35-56.

Hsu, H. Y. and Wang, S. K. (2010), 'Using Gaming Literacies to Cultivate new Literacies', Simulation and Gaming, 41 (3), 400-17.

Ke, F. and Grabowski, B. (2007), 'Gameplaying for Maths Learning: Cooperative or Not?', British Journal of Educational Technology, 38 (2), 249-59.

Kirriemuir, J. K. and McFarlane, A. (2003), 'Use of Computer and Video Games in the Classroom', proceedings of the Level Up Digital Games Research Conferences: Universiteit Utrecht, Netherlands. Available from: http://www.digra. org/dl/db/05150.28025. Retrieved January 10, 2012.

Klopfer, E. and Squire, K. (2008), 'Environmental Detectives - The Development of an Augmented Reality Platform for Environmental Simulations', Educational Technology: Research and Development, 56 (2), 203-28.

Lim, G. (2001), 'A Framework for Integrating Technologies in Teaching and Learning', in Price, J. et al., Proceedings of Society for Information Technology and Teacher Education International Conference 2001, Chesapeake, VA: AACE, pp. 2751-56.

Mackereth, M. and Anderson, J. (2000), 'Computers, Video Games, Literacy: What Do Girls Think?', Australian Journal of Language and Literacy, 23 (3), 184-96.

Marsh, J. (2004), 'The Techno-Literacy Practices of Young Children', Journal of Early Childhood Research, 2 (1), 51-66.

McFarlane, A., Sparrowhawk, A. and Heald, Y. (2002), 'Report on the Educational use of Games: An Exploration by TEEM of the Contribution Which Games can Make to the Education Process', (Online). Available from: http://educationarcade. org/files/videos/conf2005/Angela\%20MacFarlane-2.pdf. Retrieved January 6, 2012.

Mercer, N., Dawes, L., Wegerif, R., Sams, C. and Fernandez, M. (2007), 'Computers, Literacy and Thinking Together', in Adams, A. and Brindley, S., Teaching Secondary English with ICT, Berkshire: Open University Press, pp. 1-17.

Moreno-Ger, P., Burgos, D. and Torrente, J. (2009), 'Digital Games in eLearning Environments', Simulation and Gaming, 40 (5), 669-87.

Owston, R., Wideman, H., Ronda, N. S. and Brown, C. (2009), 'Computer Game Development as a Literacy Activity', Computers and Education, 53 (3), 977-89.

Papastergiou, M. (2009), 'Digital Game-Based Learning in High School Computer Science Education: Impact on Educational Effectiveness and Student Motivation', Computers and Education, 52 (1), 1-12. 
Papaioannou, P. and Charalambous, K. (2011), 'Principals' Attitudes Towards ICT and Their Perceptions About the Factors That Facilitate or Inhibit ICT Integration in Primary Schools of Cyprus', Journal of Information Technology Education, 10, 349-69.

Penuel, W., Pasnik, S., Bates, L., Townsend, E., Gallagher, L., Llorente, C. and Hupert, N. (2009), Preschool Teachers Can Use a Media-Rich Curriculum to Prepare Low-Income Children for School Success: Results of a Randomized Controlled Trail, New York and Menlo Park, CA: Education Development Centre, Inc., and SRI International.

Peterson, M. (2010), 'Computerized Games and Simulations in Computer-Assisted Language Learning: A Meta-Analysis of Research', Simulation and Gaming, 41 (1), 72-93.

Prensky, M. (2006), 'Don't Bother Me Mom - I'm Learning!', Minnesota: Paragon House.

Rice, J. W. (2007), 'New Media Resistance: Barriers to Implementation of Computer Video Games in the Classroom', Journal of Educational Multimedia and Hypermedia, 16 (3), 249-61.

Rickard, W. and Oblinger, D. (2004), Higher Education Leaders Symposium: Unlocking the Potential of Gaming Technology, Microsoft Corporation. Available from: http://net.educause.edu/ir/library/pdf/NLI0425.pdf. Retrieved January 13, 2012.

Robertson, J. and Howells, C. (2008), 'Computer Game Design: Opportunities for Successful Learning', Computers and Education, 50 (2), 559-78.

Rosas, R., Nussbaum, M., Cumsille, P., Marianov, V., Correa, M., Flores, P., Grau, V., Lagos, F., Lopez, X., Lopez, V., Rodriguez, P. and Salinas, M. (2003), 'Beyond Nintendo: Design and Assessment of Educational Video Games for First and Second Grade Students', Computers and Education, 40 (1), 71-94.

Roschelle, J., Pea, R., Hoadley, C., Gordin, D. and Means, B. (2001), 'Changing How and What Children Learn in School with Computer-Based Technologies', Future of Children, 10 (2), 76-101.

Sandford, R., Ulicsak, M., Facer, K. and Rudd, T. (2006), Teaching with Games: Using Commercial off-the-Shelf Computer Games in Formal Education, Bristol: Furturelab.

Sanford, K. and Madill, L. (2007), 'Understanding the Power of New Literacies Through Video Game Play and Design', Canadian Journal of Education, 30 (2), 432-55.

Selwyn, N. (1999), 'Students' Attitudes Towards Computers in Sixteen to Nineteen Education', Education and Information Technologies, 4 (2), 129-41.

Shaffer, D. W., Squire, K. R., Halverson, R. and Gee, J. P. (2005), 'Video Games and the Future of Learning', Phi Delta Kappan, 87 (2), 105-11.

Shields, M. K. and Behrman, R. E. (2000), "Children and Computer Technology: Analysis and Recommendations', Children and Computer Technology, 10 (2), 4-30.

Squire, K. (2003), 'Video Games in Education', International Journal of Intelligent Games and Simulation, 2 (1), 49-62.

- (2008), 'Video Game-Based Learning: An Emerging Paradigm for Instruction', Performance Improvement Quarterly, 21 (2), 7-36.

Tao, Y. H., Cheng, C. J. and Sun, S. Y. (2009), 'What Influences College Students to Continue Using Business Simulation Games? The Taiwan Experience', Computers and Education, 53 (3), 929-39.

Tuzun, H. (2007), 'Blending Video Games with Learning: Issues and Challenges with Classroom Implementations in the Turkish Context', British Journal of Educational Technology, 38 (3), 465-77. 
Tuzun, H., Yilmaz-Soylu, M., Karakus, T., Inal, Y. and Kizilkaya, G. (2009), 'The Effects of Computer Games on Primary School students' Achievement and Motivation in Geography Learning', Computers and Education, 52 (1), 68-77.

Walsh, K. (2002), IcT's About Learning: School Leadership and the Effective Integration of Information and Communication Technology, Accessed from: http://dera.ioe.ac.uk/5077/1/walsh-ict-full.pdf. Retrieved January 11, 2012.

Watson, W. R., Mong, C. J. and Harris, C. A. (2011), 'A Case Study of the In-Class use of a Video Game for Teaching High School History', Computers \& Education, $56(2), 466-74$.

Winn, W. (2002), 'Current Trends in Educational Technology Research: The Study of Learning Environments', Educational Psychology Review, 14 (3), 331-51.

\section{Address for correspondence}

Charles L. Mifsud, Centre for Literacy, University of Malta, Msida, MSD 2080, Malta.E-mail: charles.l.mifsud@um.edu.mt 